Eleni Polymenopoulou*

epolymenopoulou@hbku.edu.qa

orcid.org/0000-0003-4331-933X

Hamad Bin Khalifa University

College of Law

Qatar Foundation

Qatar

\title{
"Cultural Diversity" from the Perspective of Human Rights, Media, and Trade Law: Cross-Fertilization or Conflict?
}

\begin{abstract}
Over the last twenty years, a number of high-level policy meetings have emphasized the significance of cultural diversity in all matters related to international cultural cooperation. Instruments negotiated both in the context of the UNESCO and other agencies of the United Nations demonstrate the pervasive interest of the international community in strategies enhancing cultural diversity. Yet the concept of diversity is a particularly broad one, entrenched on a variety of rationales for its protection, such as the promotion of human rights and democratic participation; sustainable and human development; protection of cultural industries vis-à-vis the liberalisation of audio-visual services and free trade; promotion of intercultural and interreligious dialogue; as well as protection of cultural rights and cultural heritage. As this article submits, the promotion of cultural diversity is a laudable cause in and of itself, and a first step towards achieving equality. Its omnipresence, however, taken in conjunction with its imprecise content and function in the cultural market (in accordance with the 2005 UNESCO Convention on the
\end{abstract}

\footnotetext{
* Eleni Polymenopoulou is an Assistant Professor, Hamad Bin Khalifa University, College of Law, Qatar Foundation; and Adjunct Assistant Professor, Georgetown University, Edmund A Walsh School of Foreign Service. She was awarded a Master in Law and a PhD in Human Rights Law from the University of Grenoble-Alpes (France). She has also studied arts at Ornerakis School of Applied Arts, and has published children books as an author and illustrator. She has written a monograph on Artistic Freedom in International Law (Cambridge University Press, Cambridge 2022, forthcoming).
} 


\section{GENERAL ARTICLES}

Eleni Polymenopoulou

Promotion of Cultural Expressions) runs the risk of downplaying its significance and effectiveness.

Keywords: cultural diversity, human rights, media, trade law, participation

\section{Introduction}

The proliferation of debates on equality has both reflected and led to a renewed interest in "diversity" discourse. A plain Google search of the term "cultural diversity" brings up about 37 million results (as a measure of comparison, the term "human rights law" brings up only 10 million results, and "the Beatles" about 60 million results). The notion of diversity is far from being understood as gender diversity ${ }^{1}$ alone. Culture, race, and ethnicity are now clearly part of the diversity narrative, especially following the sweeping influence of the Black Lives Matter (BLM) movement in many parts of the world. ${ }^{2}$ Sexual diversity and gender variance are also gradually accepted in both the academic discourse ${ }^{3}$ and in soft law instruments. ${ }^{4}$

Cultural diversity however may be the only one of the many diversity narratives that is so well entrenched in international instruments. The Principles of International Cultural Cooperation of 1966 was the first United Nations instrument that aimed specifically at its promotion, ${ }^{5}$ while the statute of the United Nations Educational, Scientific and Cultural Organization (UNESCO) itself states that it has been set up to preserve "the independence, integrity and fruitful diversity of cultures and

1 See, indicatively, M. Silvestri, Gender Diversity: Two Steps Forward, One Step Back, "Policing: A Journal of Policy and Practice" 2015, Vol. 9(1), pp. 56-64; B. Choudhury, New Rationales for Women on Boards, "Oxford Journal of Legal Studies" 2014, Vol. 34(3), pp. 511-542 (arguing that rationales for increasing women on boards should be based on both equality and economic grounds).

2 L. Buchanan, Q. Bui, J.K. Patel, Black Lives Matter May Be the Largest Movement in U.S. History, "New York Times", 3 July 2021, https://www.nytimes.com/interactive/2020/07/03/us/george-floyd-protests-crowdsize.html [accessed: 24.09.2021]. See, generally, E. Polymenopoulou, Expressing Dissent: Gag Laws, Human Rights Activism and the Right to Protest, "Florida Journal of International Law" 2021, Vol. 32(1).

3 More recently, see V. Hamzic, Sexual and Gender Diversity in the Muslim World: History, Law and Vernacular Knowledge, I.B. Tauris, London 2019; for a brief overview of recent developments, see also E. Polymenopoulou, Same-Sex Narratives and LGBTI Activism in the Muslim World, 18 May 2020, https://gjia.georgetown. edu/2020/05/18/same-sex-narratives-and-Igbti-activism-in-muslim-world/ [accessed: 24.09.2021].

4 The Yogyakarta Principles: Principles on the Application of International Human Rights Law in Relation to Sexual Orientation and Gender Identity, March 2007, https://www.refworld.org/pdfid/48244e602.pdf [accessed: 24.09.2021], Principles 17 (f), 24 (b), and 26 (proclaiming the right to express the diversity of sexual orientation and gender identity in cultural life, and emphasizing the need to respect diversity in all spheres, including healthcare, culture, education, and media representation).

5 Declaration of the Principles of International Cultural Co-operation, 4 November 1966, http://www.un-documents.net/dpicc.htm [accessed: 24.09.2021]. 
educational systems of the States members". ${ }^{6}$ At the national level as well governments around the world have been fervently reaffirming their commitment to "cultural diversity" - at times also passing relevant legislation.' Diversity is celebrated every year on 21 May, in accordance with Resolution 57/249 of the UN General Assembly, under the motto "think globally and act locally". Other famous days are also inspired by diversity. For example, the theme for the international museum day celebrated on 18 May 2021 was "Museums for Equality: Diversity and Inclusion".

From the perspective of international law, the recognition and safeguarding of cultural diversity has borne fruit. The diversity narrative has contributed to the emergence of substantive case-law on the acceptance of (collective) cultural claims; ${ }^{9}$ to the understanding of international law in its entirety as a rich and diverse body of norms; ${ }^{10}$ and even to making the composition of human rights bodies more diverse, reflecting the variety of legal traditions. ${ }^{11}$ And yet in normative terms, cultural diversity remains one of those open-ended terms that are hardly defined - and rarely delimited in scope. The instruments that exist today for its protection and promotion vary substantially: not only are they drafted within the context of different international bodies and agencies, but even in the context of policy making, ${ }^{12}$ as well as in different spheres or disciplines of regulation (as is the case with the "human rights law" and "trade law" regimes). As a result, enunciations of cultural diversity end up conflicting, rather than resonating, with each other.

This article aims at offering an overview of the different ways "cultural diversity" is understood across a variety of legal regimes, in particular international hu-

6 Constitution of the United Nations Educational, Scientific and Cultural Organisation, 16 November 1945, Art. 1 (on the "purposes and functions of the UNESCO").

7 A poignant example is the Executive Order on Diversity, Equity, Inclusion, and Accessibility in the Federal Workforce, issued by the President of the United States in June 2021, according to which "diversity" means "the practice of including the many communities, identities, races, ethnicities, backgrounds, abilities, cultures, and beliefs of the American people, including underserved communities" (at b). The text of the Executive Order is available at https://www.whitehouse.gov/briefing-room/presidential-actions/2021/06/25/executive-order-on-diversity-equity-inclusion-and-accessibility-in-the-federal-workforce/ [accessed: 24.09 .2021$]$.

8 http://imd.icom.museum/2020-museums-for-equality-diversity-and-inclusion/ [accessed: 24.09.2021].

9 See, generally, A. Jakubowski (ed.), Cultural Rights as Collective Rights: An International Law Perspective, Brill/Nijhoff, Leiden-Boston 2016.

10 Indicatively, A. Yusuf, Diversity of Legal Traditions and International Law: Keynote Address, "Cambridge Journal of International and Comparative Law" 2013, Vol. 2(4), pp. 681-703; C. Kessedjian, Culture et droit l'influence de la culture sur le droit international, in: P. Meerts (ed.), Culture and International Law, Hague Academic Press, The Hague 2008; also, S. Laghmani, Droit international et diversité culturelle, "Revue Générale de Droit International Public" 2008, Vol. 112(2), pp. 241-252. See also A. Xanthaki, Multiculturalism and International Law: Discussing Universal Standards, "Human Rights Quarterly" 2010, Vol. 32, p. 48 (arguing that debating on human rights and culture is needed to achieve "truly multicultural societies").

11 E.g. E. Polymenopoulou, Cultural Rights in the Case-Law of the International Court of Justice, "Leiden Journal of International Law" 2014, Vol. 27(2), pp. 447-464.

12 C. Romainville, Cultural Diversity as a Multilevel and Multifaceted Legal Notion Operating in the Law on Cultural Policies, "International Journal of Cultural Policy" 2016, Vol. 22(2). 


\section{GENERAL ARTICLES}

Eleni Polymenopoulou

man rights law; cultural law (including from the perspective of cultural heritage law, media law, and audio-visual) ${ }^{13}$ and trade law. In this sense the article attempts to adopt a holistic understanding of the meaning of diversity, exploring its normative value and assessing its effectiveness and at the same time offering it as an illustration of the problem of fragmentation of international law. In terms of structure, the article is divided into three parts. The first discusses the polysemous meaning of both "culture" and "diversity". The second part lays out the various rationales for the protection of cultural diversity, providing an overview of relevant efforts in human rights, cultural and media law, in development policies, as well as in trade law. The third part of the article attempts to reflect on the inherent limitations and challenges for diversity, and the extent to which the various norms on the protection of diversity conflict - or eventually cross-fertilize. The postulate of the article is that excessively broadening the meaning of "diversity" amounts to making it a paper tiger, i.e. a principle with no real efficiency.

\section{The Meaning of the Terms "Culture" and "Diversity": Are Words Important?}

\section{Preliminary etymological remarks}

Diversity essentially means variety - it is a word that describes a fact. The Cambridge Dictionary, for example, defines diversity not only as variety, but also "the fact of many different types of things or people being included in something"; ${ }^{14}$ and the Oxford Dictionary defines it as a practice (or quality) of "including or involving people from a range of different social and ethnic backgrounds and of different genders, sexual orientations, etc."; ${ }^{15}$ while the Dictionary of the English Language (2016) used the definition "the condition of having or including people from different ethnicities and social backgrounds". ${ }^{16}$ The best definition of cultural diversity is arguably the one found in the UNESCO Universal Declaration on Cultural Diversity ("2001 UNESCO Declaration"), which celebrated its 20th anniversary in 2021. The Declaration provides that "cultural diversity is [...] the common heritage of humanity and should be recognized and affirmed for the benefit of present and future generations" and is "as necessary for humankind as biodiversity is for nature". ${ }^{17}$ Also, according to the 2005 UNESCO Convention on the Protection and

13 For the purposes of this paper, "cultural law" is understood as both cultural heritage law and the law governing popular culture, media, and the audio-visual.

$14 \mathrm{https} / / /$ dictionary.cambridge.org/dictionary/english/diversity [accessed: 31.08.2021].

15 https://www.lexico.com/definition/diversity [accessed: 31.08.2021].

16 https://www.dictionary.com/browse/diversity [accessed: 31.08.2021].

17 Universal Declaration on Cultural Diversity, 2 November 2001, Art. 1, http://www.un-documents.net/ udcd.htm [accessed: 24.09.2021]. 
Promotion of the Diversity of Cultural Expressions ("DCE Convention"), ${ }^{18}$ diversity refers to the "manifold ways in which the cultures of groups and societies find expression" and which are "passed on within and among groups and societies". ${ }^{19}$

That said, "diversity" is arguably one of the most prominent 20 "buzzwords" at both the policy and law-making levels. Debates over the peculiar term appeared in the 1990s, exploded in the 2000s, and since then have been relentlessly expanding. In the post-Covid era, the need to enhance all types of diversity is increasingly emphasized by various types of stakeholders, businesses, and corporations, and is one of the hallmark features of marketing. ${ }^{21}$ Its effect has been sweeping in broadcasting, audio-visual media, and the press, ${ }^{22}$ as well as in the cultural sphere, especially museums ${ }^{23}$ and educational institutions. ${ }^{24}$

"Culture" on the other hand is both polysemous and broader in scope. Various attempts have been made to define its special characteristics. ${ }^{25}$ The prevalent view

1820 October 2005, 2440 UNTS 311. As of March 2021, the DCE Convention has 143 members including the EU.

19 Ibidem, Arts. 4 and 4(1). See also https://en.unesco.org/creativity/cultural-diversity-0 [accessed: 24.09.2021].

20 Indicatively, see L. Naylor (ed.), Problems and Issues of Diversity in the United States, Bergin \& Garvey, Westport, CT 1999, p. 1 (arguing in the late 1990s that "cultural diversity has become the "buzzword' of the 1990s").

21 For a critical analysis, see, indicatively, C. Oswick, M. Noon, Discourses of Diversity, Equality and Inclusion: Trenchant Formulations or Transient Fashions?, "British Journal of Management" 2014, Vol. 25(1), pp. 23-39 (contrasting diversity and inclusion, and diversity with non-discrimination options); also, OECD, All Hands In? Making Diversity Work for All, 2 September 2020, https://www.oecd.org/social/all-hands-in-making-diversity-work-for-all-efb14583-en.htm [accessed: 24.09.2021].

22 See, indicatively, BBC Commits $£ 100$ m to Increasing Diversity on TV, "BBC News", 22 June 2020, https:// www.bbc.com/news/entertainment-arts-53135022 [accessed: 24.09.2021]; European Broadcasting Union, Over 40 EBU Radio Music Channels to Support Cultural Diversity on Landmark UNESCO Date, 12 May 2021, https://www.ebu.ch/news/2021/05/over-40-ebu-radio-music-channels-to-support-cultural-diversity-on-landmark-unesco-date [accessed: 24.09.2021], and generally, World Trends in Freedom of Expression and Media Development: Global Report 2017/2018, UNESCO, Paris 2018; also, K. Robertson, New York Times Calls for Workplace Changes in Diversity Report, "New York Times", 24 February 2021, https://www.nytimes. com/2021/02/24/business/media/new-york-times-workplace-diversity.html [accessed: 24.09.2021].

23 See e.g. M. Charr, What Can Museums Teach Us About Diversity?, "Museum Next", 1 June 2020, https:// www.museumnext.com/article/what-can-museums-teach-us-about-diversity/ [accessed: 24.09.2021]; D. Fleming, Museums, Human Rights, Contested Histories and Excluded Communities, "Museum International" 2015, Vol. 67, pp. 116-120; on diversity in art education and museums generally, see S. Cahan, Z. Kocur, Contemporary Art and Multicultural Education, in: E. Joo, J. Keehn II, J. Ham-Roberts (eds.), Rethinking Contemporary Art and Multicultural Education: New Museum of Contemporary Art, Routledge, New York 2011; R. Sandell, Museums, Society, Inequality, Routledge, London 2002.

24 E.g. P. Loop, P. DeNicola, You've Committed to Increasing Gender Diversity on Your Board. Here's How to Make it Happen, "Harvard Business Review", 18 February 2019, https://hbr.org/2019/02/youve-committed-to-increasing-gender-diversity-on-your-board-heres-how-to-make-it-happen [accessed: 24.09.2021].

25 See indicatively, A. N'Daw, Towards a Definition of Culture, in: Cultural Rights as Human Rights, UNESCO, Paris 1970; K. Aoyagi, Community or Group Rights: The Definition of Culture and Its Implications, in: Cultural Rights as Human Rights, UNESCO, Paris 1970, p. 25; also, Y. Donders, Do Cultural Diversity and Human Rights Make a Good Match?, UNESCO, Paris 2010, p. 15 (making a further distinction into an objective and subjective dimension); R. O'Keefe, The "Right to Take Part in Cultural Life" under Article 15 of the ICESCR, "International and Comparative Law Quarterly" 1998, Vol. 47, p. 904. 


\section{GENERAL ARTICLES}

Eleni Polymenopoulou

is that culture is a threefold notion. In its most common sense, it refers to creativity, art, and science. ${ }^{26}$ The functioning of museums, libraries, and cultural institutions, for example, as well as access to monuments, buildings, architecture, and sites, is in this sense "culture". Secondly, it is further widely accepted that culture refers to the intellectual freedoms that are requisite for cultural production and the creative process, as well as its final products. In this sense, tangible cultural heritage, artworks, but also cultural popular arts and mass entertainment phenomena, cinema, and the audio-visual sphere are also "culture". ${ }^{27}$ Thirdly, taken in its anthropological sense "culture" encompasses a much wider range of human activities that emphasize the sentiment of belonging to a certain group, or community, or even an entire civilization. In this sense, ways of life and worldviews, value systems, traditions, and beliefs which individuals may or may not identify with are also "culture" - or civilizations. ${ }^{28}$ From this point of view, as noted by the former UN Special Rapporteur on cultural rights, Karima Bennoune, it would be more accurate to describe "culture" in the plural sense. ${ }^{29}$

\section{The Different Rationales for the Protection of Cultural Diversity}

\section{Democratic participation and enhancement of human rights protection}

The first rationale for the protection of cultural diversity is the will to achieve participation, inclusion, as well as to grant more visibility to disadvantaged individuals and groups via human rights law. From a European perspective, minority rights have served as the flagship for the enunciation of diversity in the context of Europe, following the collapse of the former Soviet Union. ${ }^{30}$ Hence, the preamble of the Framework Convention for the Protection of Minorities, for example, "consider[s] that the creation of a climate of tolerance and dialogue is necessary to enable cultural diversity to be a source and a factor, not of division, but of enrichment for each society", ${ }^{11}$ and provides that States Parties should "undertake to promote the conditions nec-

\footnotetext{
26 Y.Donders, op. cit., pp. 18-19; R. O'Keefe, op. cit., p. 905.

27 Y. Donders, op. cit., p. 19; R. O'Keefe, op. cit., p. 905.
}

28 Indicatively, Y. Donders, op. cit., p. 15: "cultures are developed and shaped by communities, which individuals identify with, building their personal cultural identity"; also, L. Pineschi, Cultural Diversity as a Human Right? General Comment No. 21 of the Committee on Economic, Social and Cultural Rights, in: S. Borelli, F. Lenzerini (eds.), Cultural Heritage, Cultural Rights, Cultural Diversity, Brill, Leiden 2012, pp. 28-29.

29 Cf. UN General Assembly, Universality, Cultural Diversity and Cultural Rights, 25 July 2018, UN Doc. A/73/227, p. 17, para. 56 ("while it is customary to do so, referring to culture in the singular has problematic methodological and epistemological consequences. It must be understood that culture is always plural. 'Culture' means cultures").

30 G. Pentassuglia, Protecting Minority Groups through Human Rights Courts: The Interpretive Role of European and Inter-American Jurisprudence, in: A.F. Vrdoljak (ed.), The Cultural Dimension of Human Rights, Oxford University Press, Oxford 2014, pp. 74-75. Also, V. Scardigli (ed.), L'Europe de la diversité: la dynamique des identités régionales, CNRS, Paris 1993, pp. 17-18.

31 Council of Europe, Framework Convention for the Protection of National Minorities, 1 February 1995, ETS No. 157, Preamble. 
essary for persons belonging to national minorities to maintain and develop their culture". ${ }^{32}$ In a broader sense, too, cultural diversity is a crucial element of the human rights discourse in achieving better social cohesion, participatory structures, and, ultimately, democratic forms of governance. The 2009 UNESCO report dedicated to diversity and intercultural dialogue explains in detail the perils of cultural uniformity. ${ }^{33}$ More and better civil society participation is therefore at the heart of cultural diversity strategies. This was also evidenced in the participation of civil society during the drafting of the 2003 Convention for the Safeguarding of the Intangible Cultural Heritage ("ICH Convention"), ${ }^{34}$ and also in the DCE Convention, in particular Article 11, which states that "parties acknowledge the fundamental role of civil society in protecting and promoting the diversity of cultural expressions" and that they "shall encourage the active participation of civil society in their efforts to achieve the objectives of this Convention". ${ }^{35}$

The drafting of universal human rights treaties provides arguably an even better example of how social struggles for equality and inclusion have influenced the formation of international law. For example, the objective of racial diversity has been among the motivations underlying the drafting of the International Convention on the Elimination of All Forms of Racial Discrimination (ICERD); ${ }^{36}$ claims for the inclusion of women led to the drafting of the Convention on the Elimination of All Forms of Discrimination against Women (CEDAW); ${ }^{37}$ and more recently the struggles for the acceptance of a social model of disability have motivated the drafting of Convention on the Rights of Persons with Disabilities (CRPD) (an under-

\footnotetext{
32 Ibidem, Art. 5.

33 Cf. UNESCO World Report: Investing in Cultural Diversity and Intercultural Dialogue, UNESCO, Paris 2009, pp. 135-143, https://en.unesco.org/interculturaldialogue/resources/130 [accessed: 24.09.2021] ("2009 UNESCO Report"), and previously also, UNESCO, Our Creative Diversity: Report of the World Commission on Culture and Development, UNESCO, Paris 1996, UNESCO Doc. CLT-96/WS-6.

3417 October 2003, 2368 UNTS 3, Art. 15; see indicatively, J. Blake, Collective Cultural Rights Considered in the Light of Recent Developments in Cultural Heritage Law, in: A. Jakubowski (ed.), op. cit., pp. 74-75; M. Jacobs, Article 15: Participation of Communities, Groups and Individuals. CGIs, Not Just 'the Community', and G. D'amico Soggetti, Article 15: Participation of Communities, Groups and Individuals - Participation and Democracy, both in: J.E. Blake, L. Lixinski (eds.), The 2003 UNESCO Intangible Heritage Convention: A Commentary, Oxford University Press, Oxford 2020.
}

35 Cf. R.J. Neuwirth, United in Divergency: A Commentary on the UNESCO Convention on the Protection and Promotion of the Diversity of Cultural Expressions, "Zeitschrift für ausländisches öffentliches Recht und Völkerrecht" 2006, Vol. 66, pp. 819-862.

3621 December 1965, 660 UNTS 195, Preamble: "[...] reaffirming that discrimination between human beings on the grounds of race, colour or ethnic origin is an obstacle to friendly and peaceful relations among nations and is capable of disturbing peace and security among peoples and the harmony of persons living side by side even within one and the same State [...]". See generally, P. Thornberry, The International Convention on the Elimination of All Forms of Racial Discrimination: A Commentary, Oxford University Press, Oxford 2016.

3718 December 1979, 1249 UNTS 13, Preamble: "Convinced that the full and complete development of a country, the welfare of the world and the cause of peace require the maximum participation of women on equal terms with men in all fields [...]". Cf. E. Brems, Human Rights: Universality and Diversity, Martinus Nijhoff Publishers, Leiden 2001, p. 21. 


\section{GENERAL ARTICLES}

Eleni Polymenopoulou

lying principle of which is specifically the "respect for difference and acceptance of persons with disabilities as part of human diversity and humanity"). ${ }^{38}$

The same logic underpins the formation of soft law. Indigenous peoples' struggles to preserve their identities have also been a catalyst in the consideration of the value of cultural diversity. ${ }^{39}$ Several provisions of the United Nations Declaration on the Rights of Indigenous People (UNDRIP) may in particular be read as advancing cultural diversity, including the proclamation of Indigenous cultural self-determination as a means of cultural survival ${ }^{40}$ and the protection of Indigenous cultural rights. ${ }^{41}$ Interestingly however, the UNDRIP is the only instrument proclaiming an independent right to cultural diversity in these words: "indigenous peoples have the right to the dignity and diversity of their cultures, traditions, histories and aspirations which shall be appropriately reflected in education and public information". ${ }^{42}$

\section{Enhancing the protection of cultural heritage and cultural rights}

A second rationale for the protection of cultural diversity is the safeguarding of cultural heritage, both tangible and intangible, for the benefit of present and future generations. On the one hand, cultural diversity is an inherent element of policies to protect tangible assets. While the term "diversity" is not explicitly stated in the text of the UNESCO Convention for the Protection of the World Cultural and Natural Heritage, ${ }^{43}$ the Intergovernmental Committee monitoring the Convention has however elaborated on a number of different occasions on the need to safeguard diversity in the preservation of heritage. ${ }^{44}$ More specifically, the World Heritage Committee has been proactive in recognizing a variety of elements for the effective management of heritage, which include an understanding of local values, and

\footnotetext{
3813 December 2006, 2515 UNTS 3, Art. 3 (d). For a commentary, see I. Bantekas, M.A. Stein, D. Anastasiou (eds.), The UN Convention on the Rights of Persons with Disabilities: A Commentary, Oxford University Press, Oxford 2018, pp. 84-105.

39 The 2007 United Nations Declaration on the Rights of Indigenous Peoples (UNDRIP) is also based on the precept of the equal value of all cultures, affirming that "all peoples contribute to the diversity and richness of civilizations and cultures, which constitute the common heritage of humankind", see UN General Assembly, United Nations Declaration on the Rights of Indigenous Peoples, 2 October 2007, UN Doc. A/RES/61/295, Preamble.

40 UNDRIP, Art. 3. Cf. Art. 43: "The rights recognized herein constitute the minimum standards for the survival, dignity and well-being of the indigenous peoples of the world".

41 E.g. Art. 11(1) guarantees "the right to maintain, protect and develop the past, present and future manifestations of their cultures"; and Art. 31 proclaims their right to "maintain, control, protect and develop their cultural heritage". See indicatively, A. Xanthaki, Culture, in: M. Weller, J. Hohmann (eds.), The UN Declaration on the Rights of Indigenous Peoples: A Commentary, Oxford University Press, Oxford 2017, pp. 39-41; also, D. Kugelmann, Protection of Minorities and Indigenous Peoples Respecting Cultural Diversity, "Max Planck Yearbook of United Nations Law" 2007, Vol. 11, pp. 238-241.
}

42 UNDRIP, Art. 15.

4316 November 1972, 1037 UNTS 151.

44 On the work of the Committee, see https://whc.unesco.org/en/. 
also "respect for diversity, equity, gender equality and human rights, and the use of inclusive and participatory planning and stakeholder consultation processes". ${ }^{45}$ It has further explained ways that biological and cultural diversity constitute tools by which to achieve sustainability. ${ }^{46}$ The ICH Convention, on the other hand, protects intangible cultural heritage as an independent type of heritage. ${ }^{47}$ It establishes obligations for States to adopt measures to promote diversity in expressions, ${ }^{48}$ including by identifying their intangible heritage and living traditions, preparing inventories, and adopting other safeguarding measures with the participation of the communities concerned. ${ }^{49}$ The Representative List of the Intangible Cultural Heritage of Humanity is per se a mechanism safeguarding cultural diversity. ${ }^{50}$

That said, the protection of cultural heritage has expanded beyond the scope of the work of UNESCO bodies. The International Covenant on Economic, Social and Cultural Rights (ICESCR), and specifically the right to "take part in cultural life" guaranteed under 15(1)(a) has been the basis of the so-called "human rights-based approach to the protection of cultural heritage"..$^{51}$ This approach has been embraced in reports of the UN Committee for Social, Economic and Cultural Rights, ${ }^{52}$ the Special Rapporteur's thematic report in $2016,{ }^{53}$ and resolutions passed by the UN Human Rights Council. ${ }^{54}$ In addition, the safeguarding of both heritage and diversity are to a certain extent an area of preoccupation also for the World Intellec-

45 UNESCO Intergovernmental Committee for the Protection of the World Cultural and Natural Heritage, Operational Guidelines for the Implementation of the World Heritage Convention, 10 July 2019, WHC.19/01, at 111 (Decisions 39 COM 11 and 43 COM 11A).

46 Ibidem, at 119 (Decision 43 COM 11A).

47 ICH Convention, Art. 2 (referring to both "practices, representations, expressions, knowledge, skills as well as the instruments, objects, artefacts and cultural spaces associated therewith"). See generally, L. Lixinski, Cultural Heritage in International Law, Oxford University Press, Oxford 2013.

48 ICH Convention, Preamble, "considering the importance of the intangible cultural heritage as a mainspring of cultural diversity and a guarantee of sustainable development [...]".

49 Ibidem, Arts. 11-24.

50 As of 2021, 492 elements corresponding to 128 countries are inscribed on the List, see https://ich.unesco.org/en/00011?type=00002\#tabs [accessed: 24.09 .2021$]$.

51 Indicatively, W. Logan, Cultural Diversity, Cultural Heritage and Human Rights: Towards Heritage Management as Human Rights-Based Cultural Practice, "International Journal of Heritage Studies" 2012, Vol. 18, pp. 231-244.

52 CESCR, General Comment No. 21: Right of Everyone to Take Part in Cultural Life (Art. 15, Para. 1 (a), of the International Covenant on Economic, Social and Cultural Rights), 21 December 2009, UN Doc. E/C.12/GC/21, para. 15 (b); see, analytically, L. Pineschi, op. cit., pp. 31-39 (discussing the broad approach adopted by the Committee and relevant State obligations).

53 Human Rights Council, Report of the Special Rapporteur in the Field of Cultural Rights, 3 February 2016, UN Doc. A/HRC/31/59; also, Human Rights Council, Report of the Independent Expert in the Field of Cultural Rights, Farida Shaheed, 21 March 2011, UN Doc. A/HRC/17/38.

54 Human Rights Council, Resolution 37/17: Cultural Rights and the Protection of Cultural Heritage, 9 April 2018, UN Doc. A/HRC/RES/37/17; Human Rights Council, Resolution 33/20: Cultural Rights and the Protection of Cultural Heritage, 6 October 2016, UN Doc. A/HRC/RES/33/20; and subsequently, Human Rights Council, Intersessional Seminar on Cultural Rights and the Protection of Cultural Heritage, 27 December 2017, UN Doc. A/HRC/37/29. 


\section{GENERAL ARTICLES}

Eleni Polymenopoulou

tual Property Organization (WIPO), especially in relation to Indigenous peoples' traditional knowledge (TK) and traditional cultural expressions (TCEs). ${ }^{55}$

\section{Promoting intercultural (and interreligious) dialogue at the global level}

A third rationale underlying cultural diversity is the promotion of intercultural dialogue at the global level. This, in and of itself, is a noble idea, based on the postulate that an understanding between peoples of various ethnic, racial, religious, and cultural backgrounds is possible, leading ultimately to peace and solidarity. The concept of "intercultural dialogue" was initiated in 2001, the year proclaimed as the Year of Dialogue among Civilizations, following a proposition from the former Iranian President, Mohammed Khatami. ${ }^{56}$ Khatami himself, however, has been a fervent opponent of Western politics and liberalism. This also raises a number of questions as to the political agenda of States endorsing the Declaration, as well as the way the Declaration impacts the discourse on international politics. ${ }^{57}$

These views were reiterated in the 2001 Durban Conference, an event that attracted significant participation by delegates from around the world. The Durban Declaration endorsed the aforementioned decision of the UN General Assembly to proclaim 2001 the year of dialogue, and was further the first occasion to formally associate diversity, dialogue between civilizations, and "common challenges to humanity that threaten shared values". ${ }^{58}$ During the event, which ironically ended a day before the 9/11 attacks, State delegates emphasized the prerogative of respect for intercultural dialogue at the global level, affirming that dialogue among civilizations "can dispel notions of cultural superiority based on racism, racial discrimination, xenophobia and related intolerance, and facilitate the building of a reconciled world for the human family". 59 Similarly, the 2001 UNESCO Declaration also affirms that respect for diversity should occur in a climate of "tolerance, dialogue and cooperation", as well as "mutual trust and understanding". 60

55 WIPO, Intergovernmental Committee on Intellectual Property and Genetic Resources, Traditional Knowledgeand Folklore, Fifth Session, Geneva, July 7 to 15, 2003, 2 May 2003, WIPO/GRTKF/IC/5/3. See generally W. Wendland, Intellectual Property and the Protection of Traditional Knowledge and Cultural Expressions, in: B. Hoffman (ed.), Art and Cultural Heritage: Law, Policy and Practice, Cambridge University Press, Cambridge 2006, p. 334; E. Polymenopoulou, Indigenous Cultural Heritage and Artistic Expressions: "Localizing" Intellectual Property Rights and UNESCO Claims, "Canadian Journal of Human Rights" 2017, Vol. 6(1), pp. 91-94 and 100-103.

56 UN General Assembly, Resolution 53/22: United Nations Year of Dialogue among Civilizations, 16 November 1998, UN Doc. A/RES/53/22; see also S.M. Khatami, Dialogue Among Civilizations: Contexts and Perspectives, https://www.un.org/en/chronicle/article/dialogue-among-civilizations-contexts-and-perspectives [accessed: 24.09.2021].

57 On the political perspective, see F. Petito, The Global Political Discourse of Dialogue among Civilizations: Mohammad Khatami, "Global Change, Peace \& Security” 2007, Vol. 19(2), pp. 103-126.

58 Report of the World Conference against Racism, Racial Discrimination, Xenophobia and Related Intolerance, Durban, 31 August - 8 September 2001, 25 January 2002, UN Doc. A/CONF.189/12.

59 Ibidem, p. 33, para. 82.

602001 UNESCO Declaration, Preamble. 
A few months after the Durban Conference and about the same time as the adoption of the 2001 UNESCO Declaration, the UN General Assembly adopted a resolution on the Global Agenda for Dialogue among Civilizations, ${ }^{61}$ and in 2004 Kofi Annan stated that "the United Nations was created in the belief that dialogue can triumph over discord, that diversity is a universal virtue and that the peoples of the world are far more united by their common fate than they are divided by their separate identities". ${ }^{62}$ Also, the World Summit Outcome document envisaged a culturally diverse world and highlighted the importance of "respect and understanding for religious and cultural diversity throughout the world". ${ }^{63}$ Two months later, on 16 December 2005, the UN General Assembly adopted the first resolution dedicated specifically to "cultural diversity". ${ }^{64}$ Other resolutions followed, in particular Resolution 62/155 adopted in December 2007, in which the UN General Assembly states that it is convinced that "dialogue among various cultures and civilizations would contribute to the efforts of all peoples and nations to enrich their cultures and traditions" 65 and is determined to "prevent and mitigate cultural homogenization, through increased intercultural exchange guided by the promotion and protection of cultural diversity". ${ }^{66}$ Similar affirmations on the significance of cultural diversity and dialogue are found also in the Durban2 conference of $2009,{ }^{67}$ as well as in the political declaration of the High-Level meeting of the UN General Assembly adopted in 2011 as a follow-up to Durban2.68

\section{Enhancing development strategies in the context of globalization}

Cultural diversity is also seen as a fundamental element of development policies. This means, first, economic development. The promotion of diversity in fact has been accelerated by research associating it with measurable economic growth and the creation of sustainable labour markets, including by managing mobility and migration. ${ }^{69}$ Several recent studies have shown that diversity in the labour

61 UN General Assembly, Resolution 56/6: Global Agenda for Dialogue among Civilizations, 9 November 2001, UN Doc. A/RES/56/6.

62 H. d'Orville, What the UN Can Do to Promote Dialogue among Civilizations, https://www.un.org/en/chronicle/article/what-un-can-do-promote-dialogue-among-civilizations [accessed: 24.09.2021].

63 UN General Assembly, Resolution 60/1: 2005 World Summit Outcome, 24 October 2005, UN Doc. $\mathrm{A} / \mathrm{RES} / 60 / 1$.

64 UN General Assembly, Resolution 60/167: Human Rights and Cultural Diversity, 7 March 2006, UN Doc. A/RES/60/167, para. 11.

65 UN General Assembly, Resolution 62/155: Human Rights and Cultural Diversity, 7 March 2008, UN Doc. A/RES/62/155, Preamble.

66 Ibidem, paras. 5 and 14. Cf. also S. von Schorlemer, Cultural Diversity, in: Max Planck Encyclopedias of International Law, Oxford University Press, Oxford 2017.

67 UN General Assembly, Outcome Document of the Durban Review Conference, adopted on 24 April 2009.

68 UN General Assembly, Draft Resolution Submitted by the President of the General Assembly: United against Racism, Racial Discrimination, Xenophobia and Related Intolerance, 16 September 2011, UN Doc. A/66/L.2.

69 Cf. 2009 UNESCO Report, pp. 15-16 and 231-238. 


\section{GENERAL ARTICLES}

Eleni Polymenopoulou

force drives creativity and innovation. ${ }^{70}$ For example, a ground-breaking study of the corporate sector and individual companies ranked in the S\&P 500 index dated 2019 made a business case for cultural diversity, finding that inclusive companies employing more diverse personnel are generally more successful. ${ }^{71}$ Development policies mean, secondly, human development. The 1982 Mexico City Declaration (proclaimed following the Mondiacult Conference, which was attended by 960 participants from 126 States), first proclaimed that culture "helps to strengthen the independence, sovereignty and identity of nations" and that there is a need to enhance human development. ${ }^{72}$ According to the Declaration, "it is vital to humanize development, the ultimate goal of which is the individual in his dignity as a human being and his responsibility to society". ${ }^{33}$ In fact, the concluding remarks of that Conference have been especially influential on the work of UNESCO in the years that followed, especially in relation to the definition of culture. The latter was defined as "the whole complex of distinctive spiritual, material, intellectual, and emotional features that characterize a society or a social group", and it was also noted that "each culture represents a unique and irreplaceable body of values". ${ }^{74} \mathrm{~A}$ careful reading of both the 1966 Principles and the Mexico City Declaration that was drafted following Mondiacult reveal the enormous influence of anthropologists on UNESCO's work, in particular Franz Boas ${ }^{75}$ and Claude Lévi-Strauss, ${ }^{76}$ who elaborated the idea that no culture is superior to another. Furthermore, the definition of culture in the Mexico City Declaration is almost a verbatim iteration of Edward Tylor's definition. ${ }^{77}$

The findings of UNESCO have found fertile ground in the work of the United Nations Development Programme (UNDP). The work of the UNDP in the first

70 Indicatively, see C. Ozgen et al., Does Cultural Diversity of Migrant Employees Affect Innovation?, "International Migration Review" 2014, Vol. 48, p. 411; also see C. Carballal-Benaglio, Cultural Diversity: Making Intercultural Collaboration Possible for Multinational Corporations, "Law \& Business Review of the Americas" 2013, Vol. 19(3), pp. 293-296.

71 See S.A. Hewlett, M. Marshall, L. Sherbin, How Diversity Can Drive Innovation, "Harvard Business Review" 2013, Vol. 2; also, D. Holger, The Business Case for More Diversity, "Wall Street Journal", 26 October 2019. See D. Bauman-Pauly, L. Trabelsi, The Business Case for Human Rights: Irrelevant or Indispensible?, in: I. Bantekas, M. Stein (eds.), Cambridge Companion to Business and Human Rights, Cambridge University Press, Cambridge 2021, pp. 115-142.

72 UNESCO, Mexico City Declaration on Cultural Policies, World Conference on Cultural Policies, Mexico City, 26 July - 6 August 1982, paras. 10-11. See also K. Matsuura, L'enjeu culturel au cœur des relations internationales, "Politique étrangère" 2006, Vol. 4, p. 1049.

73 UNESCO, Mexico City Declaration..., para. 11.

74 Ibidem, p. 1 (Preamble).

75 See, in particular, G. Stocking (ed.), A Franz Boas Reader: The Shaping of American Anthropology, 1883-1911, University of Chicago Press, Chicago 1989; also, E. Messer, Anthropology, Human Rights, and Social Transformation, in: M. Goodale (ed.), Human Rights: An Anthropological Reader, Wiley-Blackwell, Malden 2009, p. 103.

76 C. Lévi-Strauss, Structural Anthropology, Basic Books, New York 1974.

77 E. Tylor, Primitive Culture: Research into the Development of Mythology, Philosophy, Religion, Art, and Custom, J. Murray, London 1871, pp. 39-40. 
decade of the 2000s was largely influenced by the thoughts of philosopher, economist, and Nobel Prize Winner Amartya Sen (who elaborated the so-called Human Development Index, or HDI, based on a concept of development that takes into account equality, human capacity, and availability of choice). ${ }^{78}$ In particular the 2004 UNDP report, which stresses the linkages between cultural liberty and development as explained above, focuses expressly on human rights and cultural diversity as the prerequisites of development, ${ }^{79}$ as well as the eradication of poverty. ${ }^{80}$ At the same time, the idea that the promotion of cultural rights is a condition for sustainable development, including environmental protection, has become more visible at all levels of cultural rights' protection. ${ }^{81}$

\section{Opposing cultural globalization and resisting monopolies}

In addition to the above, diversity has been the flagship of the forces opposing globalization. According to the 2009 UNESCO Report, for example, "globalization is often seen as a unidirectional and unidimensional process, driven by a Western-dominated global market economy and tending to standardize, streamline and transnationalize in ways inimical to cultural diversity". ${ }^{82}$ Interestingly, the report refers to anthropologists' work, in particular that of Lévi-Strauss, whose work has been pivotal in UNESCO's earlier efforts to safeguard the world's cultural diversity and also influenced the drafting of the Mexico City Declaration, as discussed above. ${ }^{83}$

Clearly the discourse on globalization has important implications for the cultural market, especially given that the cultural and creative sector accounts roughly for about $6 \%$ of the global GDP, which potentially could rise to $10 \%$ in the near future. ${ }^{84}$ In fact, from the 1990 s onwards, the idea of "resistance" to market power, trade liberalization, and the influence of US media, in particular in the entertainment, telecommunications, audio-visual, and other cultural industries and services,

78 See UNDP, Human Development Report 1995, Oxford University Press, New York-Oxford 1995; UNDP, Human Development Report 2003: Millennium Development Goals - A Compact Among Nations to End Human Poverty, Oxford University Press, New York-Oxford 2003, p. 38. On the progress of human development, see A.B. Zampetti, Entrenching Sustainable Human Development in the Design of the Global Agenda after 2015, "Denver Journal of International Law \& Policy" 2020, Vol. 43(3), p. 277.

79 UNDP, Human Development Report 2004: Cultural Liberty in Today's Diverse World, UNDP, New York 2004, pp. 15-16. Cf. also S. von Schorlemer, op. cit., para. 2.

80 Ibidem, pp. 191-208.

81 See e.g., at the UN level, Human Rights Council, Report of the Special Rapporteur in the Field of Cultural Rights, Karima Bennoune, 10 August 2020, UN Doc. A/75/298.

822009 UNESCO Report, p. 13.

83 Ibidem, pp. 3, 19; also, UNESCO, Mexico City Declaration...

84 UNESCO, Re|shaping Cultural Policies: Advancing Creativity for Development: Monitoring the 2005 UNESCO Convention on the Protection and Promotion of the Diversity of Cultural Expressions, UNESCO, Paris 2018 ("UNESCO 2018 Report"), p. 2 (noting that "The creative economy is made up of cultural and creative industry sectors that generate annual revenues of US $\$ 2,250$ billion and global exports of over US $\$ 250$ billion"). 


\section{GENERAL ARTICLES}

Eleni Polymenopoulou

has become more pressing. Various members of the WTO, however, such as Canada, France, and the EU, have been seeking ways to boost their cultural markets, through enunciations of diversity that have been implemented at a political level in the course of intergovernmental conferences. ${ }^{85}$ Consequently, during the round of negotiations in 1994, they argued in favour of excluding the audio-visual sector from the General Agreement on Trade in Services (GATS). ${ }^{86}$ The tension became even more evident in the following round of negotiations in 2001, as reflected in the pressure for greater liberalization of free trade by the United States. ${ }^{87}$ At this juncture the aforementioned States, joined by a number of African, Asian, and Latin American States, tabled the UNESCO 2001 Declaration on Cultural Diversity, ${ }^{88}$ and later on, in 2005 , the DCE Convention. ${ }^{89}$ The latter was largely seen by its supporters as "the legal remedy to the WTO". 90

\section{Dialogue, Cross-Fertilization, or Conflict?}

\section{Conflicting meanings}

The conflicting meanings and rationales of cultural diversity necessarily impact on the effectiveness of the work undertaken for the preservation of diversity even within those spheres of regulation that are not contradictory per se - for example

85 The idea of an instrument specifically dedicated to cultural diversity was originally discussed in more narrow circles - for instance in the Francophonie meeting in Benin in June 2001; the 2001 Summit of the Americas in Quebec; and the 2001 Montreal Meeting of Professional Organizations in the Cultural Milieu. For more on the underlying debates, see T. Voon, UNESCO and the WTO: A Clash of Cultures? "International and Comparative Law Quarterly" 2006, Vol. 55(3), p. 637; L. Schéré, The Culture War: A Look at the Cultural Exception Principle in International Trade Law, "Fordham International Law Journal" 2017, Vol. 40, p. 579; E. Brooks, Cultural Imperialism vs. Cultural Protectionism: Hollywood's Response to UNESCO Efforts to Promote Cultural Diversity, "Journal of International Business \& Law" 2006, Vol. 5(1), p. 113.

86 Various WTO members however, in particular Canada, Australia, and the EU, did not make any commitments, P. Thomas, GATS and Trade in Audio-Visuals: Culture, Politics and Empire, "Economic and Political Weekly" 2003, Vol. 38(33), pp. 3485-3493; also, C.M. Bruner, UNESCO and the Future of Trade in Cultural Products, "New York University Journal of International Law and Politics" 2008, Vol. 40(351), pp. 366-370; and J. Oster, European and International Media Law, Cambridge University Press, Cambridge 2017, p. 146. 87 For more on this, see L. Schéré, op. cit., pp. 571-573 and 580-581; also, T. Voon, UNESCO and the WTO..., pp. 636-637 (noting the "stalemate" at the Uruguay round of negotiations due to the American cultural industry pushing for greater liberalization); W.-M. Choi, Screen Quota and Cultural Diversity: Debates in Korea-US FTA Talks and Convention on Cultural Diversity, "Asian Journal of WTO \& International Health Law \& Policy" 2007, Vol. 2, pp. 272-273 (noting the French government's "widely known [...] insistence on maintaining the EC's audio-visual"); E. Brooks, op. cit., p. 122 (noting that "France and Canada, despite their efforts, have also suffered the effects of cultural erosion due to the pervasive international distribution of American cultural products").

882001 UNESCO Declaration.

89 DCE Convention. The most important provision of the DCE Convention in this respect is Article 5(1), which "reaffirms [States'] sovereign right to formulate and implement their cultural policies and to adopt measures to protect and promote the diversity of cultural expressions [...]". See also T. Voon, UNESCO and the WTO...; W.-M. Choi, op. cit., p. 274.

90 L. Schéré, op. cit., p. 574. 
cultural heritage law or human rights law. A good illustration of this is the actual drafting of instruments guaranteeing diversity, in particular the DCE Convention. Apart from the problematic tension between this Convention and free trade agreements, which will be discussed below in more detail, there is an increased complexity with respect to binding obligations which States Parties must adhere to, given that it posits three sets of different objectives (nine in total) ${ }^{91}$ and lays down eight guiding principles. ${ }^{92}$ In addition, the DCE Convention builds upon State obligations that are particularly complex and broad, such as the encouragement of intercultural dialogue "with a view to ensuring wider and balanced cultural exchanges in the world in favour of intercultural respect and a culture of peace".93

\section{Overlapping competences}

The problem of overlapping competences also becomes visible when the number of stakeholders and bodies that are involved is elevated. For example, the promotion of both intercultural dialogue and cultural heritage stopped being a matter of concern for governments and political entities in fora such as the Durban Conference as it became a top priority for both UNESCO bodies as well as human rights mechanisms. This however has not been accompanied by increased dialogue between these regimes. For example, references to the work of the UNESCO Intergovernmental Committee for the DCE Convention still remain scarce in the work of the Committee on Economic, Social and Cultural Rights (CESCR). At the same time, cultural diversity and intercultural dialogue have become an area of concern also for the United Nations Sustainable Development Group, which "serves as a high-level forum for joint policy formation and decision-making" and "guides, supports, tracks and oversees the coordination of development operations". ${ }^{94}$ Since 2015, and in particular with the adoption of the new 2030 agenda for the Sustainable Development Goals (SDGs), ${ }^{95}$ diversity is also increasingly seen as a sine qua non feature of sustainable development. Yet the understanding of diversity in the context of the UNDP largely operates on the basis of a policy perspective, ${ }^{96}$ rather than human

91 DCE Convention, Art. 1(3): "the objectives of this Convention are: (a) to protect and promote the diversity of cultural expressions; (b) to create the conditions for cultures to flourish and to freely interact in a mutually beneficial manner; and (c) to encourage dialogue among cultures with a view to ensuring wider and balanced cultural exchanges in the world in favour of intercultural respect and a culture of peace".

92 Ibidem, Arts. 11-12.

93 Ibidem, Art. 1, objective (c).

94 https://undg.org/about/who-we-are [accessed: 24.09.2021].

95 UN General Assembly, Resolution 70/1: Transforming our world: the 2030 Agenda for Sustainable Development, 21 October 2015, UN Doc. A/RES/70/1, para. 26. And further, see UN General Assembly, Culture and Sustainable Development, 8 December 2015, UN Doc. A/C.2/70/L.59, affirming culture's contribution to the three dimensions of sustainable development.

96 UNDP, Human Development Report 2004, pp. 7-12, 38 (referring to the UNESCO 1969 document on cultural policy) and 47-72. 


\section{GENERAL ARTICLES}

Eleni Polymenopoulou

rights law. As Juan Telleria explains, the HDI in particular is largely based on the concept of "cultural progress", in sharp contrast with the plural meaning of culture and the concept of cultural equality. ${ }^{97}$

\section{Conflicting regimes}

In the case of self-contained regimes, such as trade law and human rights law, the differences in the way that "diversity" is understood, safeguarded, and promoted is striking. The broader problem in this respect is arguably the problem of fragmentation of international law. As suggested by the Study group on the topic, chaired by Professor Martti Koskenniemi, the problem of conflicts between rules or rule-systems is inherent in specialized law-making and the creation of self-contained regimes such as human rights law and trade law, tending "possibly [to] the loss of an overall perspective on the law". ${ }^{98}$ Regardless of the view that one adopts towards the DCE Convention (and whether or not it has been effective), ${ }^{99}$ it remains in essence an instrument that creates tensions vis-à-vis the liberalization of the cultural market. The very objectives of the DCE Convention and the promotion of cultural exchange in a spirit of equality ${ }^{100}$ are by definition in conflict with the objectives of agreements negotiated in the context of the World Trade Organization (WTO). The history of the drafting of the DCE Convention and its current rejection by the US is illustrative of these tensions. ${ }^{101}$ Free trade and the liberalization of services is far from meaning "equality" in cultural exchange. Rather, it means maintaining the status quo in music and film distribution. The DCE Convention in this sense acts as a type of protectionist regulation that aspires to set restraints on an otherwise liberalized cultural market and the oligopoly of Hollywood. ${ }^{102}$ The aim to regulate cultural production in the pursuit of a more diverse content is particularly

\footnotetext{
97 See J. Telleria, What Does Culture Mean for the UNDP?, "Cultural Studies” 2015, Vol. 29(2), p. 265.

98 International Law Commission, Fragmentation of International Law: Difficulties Arising from the Diversification and Expansion of International Law: Report of the Study Group of the International Law Commission, Finalized by Martti Koskenniemi, 13 April 2006, UN Doc. A/CN.4/L.682, at 8-9.

99 See N. Jinji, A. Tanaka, How Does UNESCO's Convention on Cultural Diversity Affect Trade in Cultural Goods?, "Journal of Cultural Economics" 2020, Vol. 44, pp. 625-660. Also, however, e.g. UNESCO 2018 Report, p. 29, noting that "between 2005 and 2014 the share of total global exports of cultural goods from developing countries (excluding China and India) increased from 15\% in 2005 to 26.5\%". Also see, indicatively, R.J. Neuwirth, The Convention on the Diversity of Cultural Expressions and its Impact on the "Culture and Trade Debate": A Critical Evaluation After 5 Years, in: T. Kono, S. Van Uytsel (eds.), The UNESCO Convention on the Diversity of Cultural Expressions: A Tale of Fragmentation in International Law, Intersentia, Antwerp 2012, pp. 236-237.
}

100 DCE Convention, Art. 2(3).

101 The full list of parties to date excludes the US, Israel, and a few others; see https://en.unesco.org/creativity/convention/parties. Analytically, see L. Schéré, op. cit., p. 575; and E. Brooks, op. cit., p. 112 (noting also that "ratification of the [DCE Convention] could potentially curtail the ability of the United States to export Hollywood films at its current rate") and 122-127.

102 Cf. C.M. Bruner, op. cit., pp. 354-355 and 378-382 (discussing the oligopoly of Hollywood and also the "love and hate" relationship between UNESCO and the US). 
visible in the Operational Guidelines on the Implementation of the Convention in the Digital Environment, which invite States to, inter alia, update their legislative and regulatory frameworks for the media in order to increase diversity at all levels of the creation, production, and diffusion of content. ${ }^{103}$

Three areas of tension between the DCE Convention and agreements negotiated in the context of the WTO appear to be particularly acute. Firstly, the DCE Convention gives a very broad definition of cultural goods and services, and clarifies that the latter may not necessarily have an economic value. ${ }^{104}$ Under the GATT and the GATS however - which aim at facilitating free exchange by lowering trade barriers in the areas of goods and services respectively - the non-economic value of cultural products or services is translated into eligibility for a "cultural exception" in favour of local cultural industries, without this being considered a "market distortion". ${ }^{105}$ This means in practice that any measures taken to support local cultural production could be justified as a measure protecting cultural diversity under the DCE Convention, including for example limitations on imports of media hardware (such as newspapers, videos, and DVDs); screen quotas in favour of domestic audio-visual production; or any other measures to boost the local music business and film industry or to protect "cultural contents". These measures are technically violations of the national treatment and non-discrimination obligations under the GATT and would be more likely to be rejected by WTO panels as inconsistent with free trade. ${ }^{106}$

Secondly, the Convention explicitly states that its purpose is to provide an opportunity to the countries of the global South to develop and promote their culture, in a spirit of solidarity. ${ }^{107}$ This is based on various provisions of the Convention, in particular obligations aimed at facilitating dialogue; ${ }^{108}$ promoting cultural

103 UNESCO, Operational Guidelines on the Implementation of the Convention in the Digital Environment, June 2017, https://en.unesco.org/creativity/node/13628 [accessed: 24.09.2021].

104 DCE Convention, Art. 1(4). For more on this, see T. Voon, UNESCO and the WTO..., p. 637 (noting that "the broad scope of the UNESCO Convention could create difficulties for the WTO treatment of many arguably 'cultural' or culture-related goods and services such as audio-visual products; books and periodicals; food, wine and spirits [especially those subject to geographical indications or otherwise of regional significance]; and tourism").

105 For more on the "cultural exception", see C.M. Bruner, op. cit., pp. 366-378; L. Shéré, op. cit., pp. 566-582; T. Voon, UNESCO and the WTO..., pp. 12-13; P. Thomas, op. cit., p. 3487 (on "Culture as Trade vs Cultural Exception"); W.-M. Choi, op. cit., p. 272 (on screen quotas); also, J. Morjin, The Place of Cultural Rights in the WTO System, in: F. Francioni, M. Scheinin (eds.), Cultural Human Rights, Martinus Nijhoff, Boston 2008, pp. 285-316; J. Shi, Free Trade and Cultural Diversity in International Law, Hart, Oxford 2013, pp. 101 and 109.

106 See e.g. World Trade Organization, Canada - Certain Measures Concerning Periodicals, 30 June 1997, WT/DS31/AB/R. See S. von Schorlemer, op. cit., para. 22.

107 See, indicatively, DCE Convention, Art. 1, objective i: "to strengthen international cooperation and solidarity in a spirit of partnership [...]" and Principle 7: "Equitable access to a rich and diversified range of cultural expressions from all over the world and access of cultures to the means of expressions and dissemination constitute important elements for enhancing cultural diversity [...]".

108 Ibidem, Art. 12. 


\section{GENERAL ARTICLES}

Eleni Polymenopoulou

cooperation and collaborations for development, as well as poverty reduction; ${ }^{109}$ and even granting preferential treatment for artists and creators of the developing world. ${ }^{110}$ Direct obligations of funding are also provided for in the DCE Convention, which establishes a fund to promote cultural diversity through collaborative initiatives and mobility programmes. ${ }^{111}$ However, these powerful provisions in favour of diversity policies are not accompanied by adequate and clear safeguards against possible abuses, other than the generic clause on the prevalence of human rights. ${ }^{112}$ Moreover, dividing the world into "developing" and "developed" countries is also vague terminology, especially in relation to the obligations emanating from the GATT, the GATS, the TRIPS, and other multilateral trade agreements. In fact, as of 2019, 109 States Parties to the DCE Convention "are recognized by UNCTAD as developing economies, economies in transition and least developed countries". ${ }^{113}$ Developed countries also run the risk of cultural uniformity, and are in equal need of boosting their cultural markets vis-à-vis monopolies. Countries such as Canada and France for example are among those that have "suffered the effects of cultural erosion due to the pervasive international distribution of American cultural products", as noted by Eireann Brooks, ${ }^{114}$ and this is precisely why they have spearheaded the efforts to promote diversity.

Thirdly, unlike the WTO dispute settlement system, the DCE Convention is accompanied by only a weak mechanism of supervision, based on cooperation and negotiation. ${ }^{115}$ And yet the DCE Convention does contain clauses on the interpretation of eventual obligations stemming from other treaties; especially Article 20 of the Convention which aspires to regulate the relationship with other instruments, recognizing that parties should perform their duties in good faith under this treaty "and all other treaties to which they are parties"; and Article 21 that compels parties to "promote the objectives and principles of this Convention in other international forums" ${ }^{116}$ The reception of these clauses by States opposing the DCE Convention has been inimical. For example, in the aftermath of the adoption of the

109 Ibidem, Arts. 13-15.

110 Ibidem, Art. 16.

111 Ibidem, Arts. 13 and 18(4).

112 Ibidem, Art. 2(1). Cf. W.-M. Choi, op. cit., p. 275.

113 List available at: https://en.unesco.org/creativity/sites/creativity/files/list_eligible_countries_10th_ ifcd_call_en_2019.pdf.

114 E. Brooks, op. cit., p. 119; L. Schéré, op. cit., pp. 567-568.

115 DCE Convention, Art. 25. See analytically, T. Voon, UNESCO and the WTO..., pp. 9-10 (on the Conduct of UNESCO Convention Parties in the WTO).

116 DCE Convention, Art. 20(1): "[...] without subordinating this Convention to any other treaty, (a) [Parties to the Convention] shall foster mutual supportiveness between this Convention and the other treaties to which they are parties [...]" and 20(2): "Nothing in this Convention shall be interpreted as modifying rights and obligations of the Parties under any other treaties to which they are parties". For a critique, see R.J. Neuwirth, The Convention on the Diversity..., p. 842. 
DCE Convention, the US Mission to UNESCO noted that "the [DCE] Convention must not be read to prevail over or modify rights and obligations under other international agreements, including WTO Agreements" and that "potential ambiguities in the [DCE] Convention must not be allowed to endanger what the global community has achieved, over many years, in the areas of free trade, the free flow of information, and freedom of choice in cultural expression and enjoyment". ${ }^{117}$

\section{Conflicting principles}

From the human rights law perspective, diversity appears to be setting an additional set of standards, arguably lowering the common denominator upon which agreement has already been entrenched. Diversity is only a first step towards the realization of equality, non-discrimination, and other human rights. The association between diversity and human rights has been the object of long-standing discussions within UNESCO. In an article published in 2007, the former Director of UNESCO Kōichirō Matsuura wrote that it is precisely human rights and liberties that are the essential guarantees of cultural diversity, in particular free speech; media freedom and pluralism; cultural rights and the right to one's language; equal access to cultural life, and so on. ${ }^{118}$ More recently, CESCR in its General Comment 21 found that the recognition of diversity is the first step towards the elimination of discrimination, ${ }^{119}$ and the UN Special Rapporteur Karima Bennoune in her 2018 report on cultural rights recognized that non-discrimination provides a legal basis for diversity. ${ }^{120}$ This is an important point in avoiding misconceptions about the normative content of diversity. Non-discrimination and equality obligations are both prerequisites and the legal basis for States to be able to realize diversity through accommodating the various cultural claims. ${ }^{121}$ This is also demonstrated by the numerous relevant judgments and decisions of human rights bodies, not only with respect to minority and Indigenous peoples' rights (for example, with respect to the promotion of cul-

117 L. Schéré, op. cit., p. 574; T. Voon, UNESCO and the WTO..., p. 635; also, T. Voon, Culture, Human Rights, and the WTO, in: A.F. Vrdoljak (ed.), The Cultural Dimension of Human Rights, Oxford University Press, Oxford 2014, pp. 186-202.

118 K. Matsuura, op. cit., p. 1047.

119 CESCR, op. cit., para. 23: "a first and important step towards the elimination of discrimination, whether direct or indirect, is for States to recognize the existence of diverse cultural identities of individuals and communities on their territories".

120 UN General Assembly, Universality..., para. 23 (pointing to the fact that the "principle of non-discrimination, enshrined in a large number of international legal instruments, constitutes an important legal basis for the relationship between universality and diversity").

121 Indicatively, see A.F. Vrdoljak, Liberty, Equality, Diversity: States, Cultures, and International Law, in: A.F. Vrdoljak (ed.), The Cultural Dimension of Human Rights, Oxford University Press, Oxford 2014; also, R. Wintemute, Accommodating Religious Beliefs: Harm, Clothing or Symbols, and Refusals to Serve Others, "Modern Law Review" 2014, Vol. 77, p. 223. 


\section{GENERAL ARTICLES}

Eleni Polymenopoulou

tural traditions and ways of life), but also in the area of media pluralism. ${ }^{122}$ However, the emphasis on the promotion of diversity by a variety of entities, agencies, and bodies risks shifting the focus away from equality considerations. The same can be said for State obligations to abide by diversity standards, as in the case of the DCE Convention, which subjects the right of States to adopt measures aiming at the promotion of diversity to the principle of sovereignty. ${ }^{123}$ While the rationale of this Convention has been primarily protectionist, as explained in the previous section, taken in the context of human rights law, and given the complexity and imprecision of its exact scope, such enunciations risk blurring the legal and non-legal components of diversity. Surely non-discrimination and equality contribute to enforcing pluralism and can provide more fertile grounds for making diversity an operative and effective principle. Contrary to well-defined obligations concerning non-discrimination and equality in human rights law however (especially vis-à-vis minorities, migrants, and other vulnerable and socially excluded groups), diversity obligations are a priori non-justiciable.

\section{Conclusions}

Diversity is an amazing phenomenon and its safeguarding is undoubtedly of vital significance in order to maintain the cultural richness of our world and transmit knowledge, skills, and happiness to future generations. The less culturally diverse our world is, the more impoverished the human experience is. Cultural diversity, however, is not only about those who are learning the skills of one art or another, but also about economic considerations. It is important to safeguard expressions of one particular way of life in sustainable economic terms, as well as allow cultural (and audio-visual) production to circulate freely in a spirit of equality and diversity. Over-emphasizing cultural diversity, however, significantly risks downplaying human rights norms. What is crucial in this respect is to clarify the meaning one gives to the term "diversity". It is human rights obligations, rather than soft law in the form of UNESCO norms, that are vital to compelling States to enable and enhance the equal participation of all groups in cultural life, especially vulnerable groups. In addition, the multiplicity of actors involved in the promotion of diversity is not necessarily indicative of better or more effective protection. Cultural diversity requires preservation and is indeed a crucial element of multicultural societies and

122 E.g. European Court of Human Rights, Meltex Ltd. and Mesrop Movsesyan v. Armenia, Application No. 32283/04, Judgment of 17 September 2008; also, e.g. Inter-American Court of Human Rights, Granier et al. (Radio Caracas Television - RCTV) v. Venezuela, Judgment of 22 June 2015 (in which the IACtHR found that the reforms in licensing processes were "against the spirit of pluralism" as their purpose was to silence voices critical of the government).

123 DCE Convention, Art. 5: "the parties [...] reaffirm their sovereign right to formulate and implement their cultural policies and to adopt measures to protect and promote the diversity of cultural expressions and to strengthen international cooperation to achieve the purposes of this Convention". 
"global" pluralism. However, the emphasis from a normative perspective should be less on proclaiming diversity across various fora, and more on working on the ground for a better implementation of social, economic, and cultural rights, as well as the principles of non-discrimination and equality. In other words, excessively broadening the concept of cultural diversity runs the risk of coalescence - if not substitution - of the value of diversity with justiciable rights and principles of human rights law such as equality and non-discrimination. In this way the promotion of cultural diversity loses its effectiveness and is reduced to solemn, yet empty, words.

\section{References}

Aoyagi K., Community or Group Rights: The Definition of Culture and Its Implications, in: Cultural Rights as Human Rights, UNESCO, Paris 1970.

Bantekas I., Stein M.A., Anastasiou D. (eds.), The UN Convention on the Rights of Persons with Disabilities: A Commentary, Oxford University Press, Oxford 2018.

Bauman-Pauly D., Trabelsi L., The Business Case for Human Rights: Irrelevant or Indispensible?, in: I. Bantekas, M. Stein (eds.), Cambridge Companion to Business and Human Rights, Cambridge University Press, Cambridge 2021.

BBC Commits $£ 100 m$ to Increasing Diversity on TV, "BBC News", 22 June 2020, https://www. bbc.com/news/entertainment-arts-53135022 [accessed: 24.09.2021].

Blake J., Collective Cultural Rights Considered in the Light of Recent Developments in Cultural Heritage Law, in: A. Jakubowski (ed.), Cultural Rights as Collective Rights: An International Law Perspective, Brill/Nijhoff, Leiden-Boston 2016.

Brems E., Human Rights: Universality and Diversity, Martinus Nijhoff Publishers, Leiden 2001.

Brooks E., Cultural Imperialism vs. Cultural Protectionism: Hollywood's Response to UNESCO Efforts to Promote Cultural Diversity, "Journal of International Business \& Law" 2006, Vol. 5(1).

Bruner C.M., UNESCO and the Future of Trade in Cultural Products, "New York University Journal of International Law and Politics" 2008, Vol. 40(351).

Buchanan L., Bui Q., Patel J.K., Black Lives Matter May Be the Largest Movement in U.S. History, "New York Times", 3 July 2021, https://www.nytimes.com/interactive/2020/07/03/ us/george-floyd-protests-crowd-size.html [accessed: 24.09.2021].

Cahan S., Kocur Z., Contemporary Art and Multicultural Education, in: E. Joo, J. Keehn II, J. Ham-Roberts (eds.), Rethinking Contemporary Art and Multicultural Education: New Museum of Contemporary Art, Routledge, New York 2011.

Carballal-Benaglio C., Cultural Diversity: Making Intercultural Collaboration Possible for Multinational Corporations, "Law \& Business Review of the Americas" 2013, Vol. 19(3).

CESCR, General Comment No. 21: Right of Everyone to Take Part in Cultural Life (Art. 15, Para. 1 (a), of the International Covenant on Economic, Social and Cultural Rights), 21 December 2009, UN Doc. E/C.12/GC/21.

Charr M., What Can Museums Teach Us About Diversity?, "Museum Next", 1 June 2020, https://www.museumnext.com/article/what-can-museums-teach-us-about-diversity/ [accessed: 24.09.2021].

Choi W.-M., Screen Quota and Cultural Diversity: Debates in Korea-US FTA Talks and Convention on Cultural Diversity, "Asian Journal of WTO \& International Health Law \& Policy" 2007, Vol. 2. 


\section{GENERAL ARTICLES}

Eleni Polymenopoulou

Choudhury B., New Rationales for Women on Boards, "Oxford Journal of Legal Studies" 2014, Vol. 34(3).

Constitution of the United Nations Educational, Scientific and Cultural Organisation, 16 November 1945.

Convention for the Protection of the World Cultural and Natural Heritage, 16 November 1972, 1037 UNTS 151.

Convention for the Safeguarding of the Intangible Cultural Heritage, 17 October 2003, 2368 UNTS 3.

Convention on the Elimination of All Forms of Discrimination against Women, 18 December 1979, 1249 UNTS 13

Convention on the Protection and Promotion of the Diversity of Cultural Expressions, 20 October 2005, 2440 UNTS 311.

Convention on the Rights of Persons with Disabilities, 13 December 2006, 2515 UNTS 3.

Council of Europe, Framework Convention for the Protection of National Minorities, 1 February 1995, ETS No. 157.

D'amico Soggetti G., Article 15: Participation of Communities, Groups and Individuals - Participation and Democracy, in: J.E. Blake, L. Lixinski (eds.), The 2003 UNESCO Intangible Heritage Convention: A Commentary, Oxford University Press, Oxford 2020.

d'Orville H., What the UN Can Do to Promote Dialogue among Civilizations, https://www.un.org/en/chronicle/article/what-un-can-do-promote-dialogue-among-civilizations [accessed: 24.09.2021].

Declaration of the Principles of International Cultural Co-operation, 4 November 1966, http:// www.un-documents.net/dpicc.htm [accessed: 24.09.2021].

Donders Y., Do Cultural Diversity and Human Rights Make a Good Match?, UNESCO, Paris 2010.

European Broadcasting Union, Over 40 EBU Radio Music Channels to Support Cultural Diversity on Landmark UNESCO Date, 12 May 2021, https://www.ebu.ch/news/2021/05/ over-40-ebu-radio-music-channels-to-support-cultural-diversity-on-landmark-unesco-date [accessed: 24.09.2021].

European Court of Human Rights, Meltex Ltd. and Mesrop Movsesyan v. Armenia, Application No. 32283/04, Judgment of 17 September 2008.

Fleming D., Museums, Human Rights, Contested Histories and Excluded Communities, "Museum International" 2015, Vol. 67.

Hamzic V., Sexual and Gender Diversity in the Muslim World: History, Law and Vernacular Knowledge, I.B. Tauris, London 2019.

Hewlett S.A., Marshall M., Sherbin L., How Diversity Can Drive Innovation, "Harvard Business Review" 2013, Vol. 2.

Holger D., The Business Case for More Diversity, "Wall Street Journal", 26 October 2019.

Human Rights Council, Intersessional Seminar on Cultural Rights and the Protection of Cultural Heritage, 27 December 2017, UN Doc. A/HRC/37/29.

Human Rights Council, Report of the Independent Expert in the Field of Cultural Rights, Farida Shaheed, 21 March 2011, UN Doc. A/HRC/17/38.

Human Rights Council, Report of the Special Rapporteur in the Field of Cultural Rights, 3 February 2016, UN Doc. A/HRC/31/59.

Human Rights Council, Report of the Special Rapporteur in the Field of Cultural Rights, Karima Bennoune, 10 August 2020, UN Doc. A/75/298.

Human Rights Council, Resolution 33/20: Cultural Rights and the Protection of Cultural Heritage, 6 October 2016, UN Doc. A/HRC/RES/33/20. 
Human Rights Council, Resolution 37/17: Cultural Rights and the Protection of Cultural Heritage, 9 April 2018, UN Doc. A/HRC/RES/37/17.

Inter-American Court of Human Rights, Granier et al. (Radio Caracas Television - RCTV) v. Venezuela, Judgment of 22 June 2015.

International Convention on the Elimination of All Forms of Racial Discrimination, 21 December 1965, 660 UNTS 195.

International Law Commission, Fragmentation of International Law: Difficulties Arising from the Diversification and Expansion of International Law: Report of the Study Group of the International Law Commission, Finalized by Martti Koskenniemi, 13 April 2006, UN Doc. A/CN.4/L.682.

Jacobs M., Article 15: Participation of Communities, Groups and Individuals. CGIs, Not Just 'the Community', in: J.E. Blake, L. Lixinski (eds.), The 2003 UNESCO Intangible Heritage Convention: A Commentary, Oxford University Press, Oxford 2020.

Jakubowski A. (ed.), Cultural Rights as Collective Rights: An International Law Perspective, Brill/ Nijhoff, Leiden-Boston 2016.

Jinji N., Tanaka A., How Does UNESCO's Convention on Cultural Diversity Affect Trade in Cultural Goods?, "Journal of Cultural Economics" 2020, Vol. 44.

Kessedjian C., Culture et droit - l'influence de la culture sur le droit international, in: P. Meerts (ed.), Culture and International Law, Hague Academic Press, The Hague 2008.

Khatami S.M., Dialogue Among Civilizations: Contexts and Perspectives, https://www.un.org/ en/chronicle/article/dialogue-among-civilizations-contexts-and-perspectives [accessed: 24.09.2021].

Kugelmann D., Protection of Minorities and Indigenous Peoples Respecting Cultural Diversity, "Max Planck Yearbook of United Nations Law" 2007, Vol. 11.

Laghmani S., Droit international et diversité culturelle, "Revue Générale de Droit International Public" 2008, Vol. 112(2).

Lévi-Strauss C., Structural Anthropology, Basic Books, New York 1974.

Lixinski L., Cultural Heritage in International Law, Oxford University Press, Oxford 2013.

Logan W., Cultural Diversity, Cultural Heritage and Human Rights: Towards Heritage Management as Human Rights-Based Cultural Practice, "International Journal of Heritage Studies" 2012, Vol. 18.

Loop P., DeNicola P., You've Committed to Increasing Gender Diversity on Your Board. Here's How to Make it Happen, "Harvard Business Review", 18 February 2019, https://hbr. org/2019/02/youve-committed-to-increasing-gender-diversity-on-your-board-heres-how-to-make-it-happen [accessed: 24.09.2021].

Matsuura K., L'enjeu culturel au cœur des relations internationales, "Politique étrangère" 2006, Vol. 4.

Messer E., Anthropology, Human Rights, and Social Transformation, in: M. Goodale (ed.), Human Rights: An Anthropological Reader, Wiley-Blackwell, Malden 2009.

Morjin J., The Place of Cultural Rights in the WTO System, in: F. Francioni, M. Scheinin (eds.), Cultural Human Rights, Martinus Nijhoff, Boston 2008.

N'Daw A., Towards a Definition of Culture, in: Cultural Rights as Human Rights, UNESCO, Paris 1970.

Naylor L. (ed.), Problems and Issues of Diversity in the United States, Bergin \& Garvey, Westport, CT 1999.

Neuwirth R.J., The Convention on the Diversity of Cultural Expressions and its Impact on the "Culture and Trade Debate": A Critical Evaluation After 5 Years, in: T. Kono, S. Van Uytsel (eds.), The UNESCO Convention on the Diversity of Cultural Expressions: A Tale of Fragmentation in International Law, Intersentia, Antwerp 2012. 


\section{GENERAL ARTICLES}

Eleni Polymenopoulou

Neuwirth R.J., United in Divergency: A Commentary on the UNESCO Convention on the Protection and Promotion of the Diversity of Cultural Expressions, "Zeitschrift für ausländisches öffentliches Recht und Völkerrecht" 2006, Vol. 66.

O'Keefe R., The "Right to Take Part in Cultural Life" under Article 15 of the ICESCR, "International and Comparative Law Quarterly" 1998, Vol. 47.

OECD, All Hands In? Making Diversity Work for All, 2 September 2020, https://www.oecd. org/social/all-hands-in-making-diversity-work-for-all-efb14583-en.htm [accessed: 24.09.2021].

Oster J., European and International Media Law, Cambridge University Press, Cambridge 2017.

Oswick C., Noon M., Discourses of Diversity, Equality and Inclusion: Trenchant Formulations or Transient Fashions?, "British Journal of Management" 2014, Vol. 25(1).

Ozgen C. et al., Does Cultural Diversity of Migrant Employees Affect Innovation?, "International Migration Review" 2014, Vol. 48.

Pentassuglia G., Protecting Minority Groups through Human Rights Courts: The Interpretive Role of European and Inter-American Jurisprudence, in: A.F. Vrdoljak (ed.), The Cultural Dimension of Human Rights, Oxford University Press, Oxford 2014.

Petito F., The Global Political Discourse of Dialogue among Civilizations: Mohammad Khatami, "Global Change, Peace \& Security" 2007, Vol. 19(2).

Pineschi L., Cultural Diversity as a Human Right? General Comment No. 21 of the Committee on Economic, Social and Cultural Rights, in: S. Borelli, F. Lenzerini (eds.), Cultural Heritage, Cultural Rights, Cultural Diversity, Brill, Leiden 2012.

Polymenopoulou E., Cultural Rights in the Case-Law of the International Court of Justice, "Leiden Journal of International Law" 2014, Vol. 27(2).

Polymenopoulou E., Expressing Dissent: Gag Laws, Human Rights Activism and the Right to Protest, "Florida Journal of International Law" 2021, Vol. 32(1).

Polymenopoulou E., Indigenous Cultural Heritage and Artistic Expressions: "Localizing" Intellectual Property Rights and UNESCO Claims, "Canadian Journal of Human Rights" 2017, Vol. 6(1).

Polymenopoulou E., Same-Sex Narratives and LGBTI Activism in the Muslim World, 18 May 2020, https://gjia.georgetown.edu/2020/05/18/same-sex-narratives-and-lgbti-activism-in-muslim-world/ [accessed: 24.09.2021].

President of the United States, Executive Order on Diversity, Equity, Inclusion, and Accessibility in the Federal Workforce, 25 June 2021, https://www.whitehouse.gov/briefing-room/presidential-actions/2021/06/25/executive-order-on-diversity-equity-inclusion-and-accessibility-in-the-federal-workforce/ [accessed: 24.09.2021].

Report of the World Conference against Racism, Racial Discrimination, Xenophobia and Related Intolerance, Durban, 31 August - 8 September 2001, 25 January 2002, UN Doc. A/CONF.189/12.

Robertson K., New York Times Calls for Workplace Changes in Diversity Report, "New York Times", 24 February 2021, https://www.nytimes.com/2021/02/24/business/media/ new-york-times-workplace-diversity.html [accessed: 24.09.2021].

Romainville C., Cultural Diversity as a Multilevel and Multifaceted Legal Notion Operating in the Law on Cultural Policies, "International Journal of Cultural Policy" 2016, Vol. 22(2).

Sandell R., Museums, Society, Inequality, Routledge, London 2002.

Scardigli V. (ed.), L'Europe de la diversité: la dynamique des identités régionales, CNRS, Paris 1993. 
Schéré L., The Culture War: A Look at the Cultural Exception Principle in International Trade Law, "Fordham International Law Journal" 2017, Vol. 40.

Schorlemer S. von, Cultural Diversity, in: Max Planck Encyclopedias of International Law, Oxford University Press, Oxford 2017.

Shi J., Free Trade and Cultural Diversity in International Law, Hart, Oxford 2013.

Silvestri M., Gender Diversity: Two Steps Forward, One Step Back, "Policing: A Journal of Policy and Practice" 2015, Vol. 9(1).

Stocking G. (ed.), A Franz Boas Reader: The Shaping of American Anthropology, 1883-1911, University of Chicago Press, Chicago 1989.

Telleria J., What Does Culture Mean for the UNDP?, "Cultural Studies" 2015, Vol. 29(2).

The Yogyakarta Principles: Principles on the Application of International Human Rights Law in Relation to Sexual Orientation and Gender Identity, March 2007, https://www.refworld. org/pdfid/48244e602.pdf [accessed: 24.09.2021].

Thomas P., GATS and Trade in Audio-Visuals: Culture, Politics and Empire, "Economic and Political Weekly" 2003, Vol. 38(33).

Thornberry P., The International Convention on the Elimination of All Forms of Racial Discrimination: A Commentary, Oxford University Press, Oxford 2016.

Tylor E., Primitive Culture: Research into the Development of Mythology, Philosophy, Religion, Art, and Custom, J. Murray, London 1871.

UN General Assembly, Culture and Sustainable Development, 8 December 2015, UN Doc. A/C.2/70/L.59.

UN General Assembly, Draft Resolution Submitted by the President of the General Assembly: United against Racism, Racial Discrimination, Xenophobia and Related Intolerance, 16 September 2011, UN Doc. A/66/L.2.

UN General Assembly, Outcome Document of the Durban Review Conference, adopted on 24 April 2009.

UN General Assembly, Resolution 53/22: United Nations Year of Dialogue among Civilizations, 16 November 1998, UN Doc. A/RES/53/22.

UN General Assembly, Resolution 56/6: Global Agenda for Dialogue among Civilizations, 9 November 2001, UN Doc. A/RES/56/6.

UN General Assembly, Resolution 60/1: 2005 World Summit Outcome, 24 October 2005, UN Doc. A/RES/60/1.

UN General Assembly, Resolution 60/167: Human Rights and Cultural Diversity, 7 March 2006, UN Doc. A/RES/60/167.

UN General Assembly, Resolution 62/155: Human Rights and Cultural Diversity, 7 March 2008, UN Doc. A/RES/62/155.

UN General Assembly, Resolution 70/1: Transforming our world: the 2030 Agenda for Sustainable Development, 21 October 2015, UN Doc. A/RES/70/1.

UN General Assembly, United Nations Declaration on the Rights of Indigenous Peoples, 2 October 2007, UN Doc. A/RES/61/295.

UN General Assembly, Universality, Cultural Diversity and Cultural Rights, 25 July 2018, UN Doc. A/73/227.

UNDP, Human Development Report 1995, Oxford University Press, New York-Oxford 1995.

UNDP, Human Development Report 2003: Millennium Development Goals - A Compact Among Nations to End Human Poverty, Oxford University Press, New York-Oxford 2003.

UNDP, Human Development Report 2004: Cultural Liberty in Today's Diverse World, UNDP, New York 2004. 


\section{GENERAL ARTICLES}

Eleni Polymenopoulou

UNESCO Intergovernmental Committee for the Protection of the World Cultural and Natural Heritage, Operational Guidelines for the Implementation of the World Heritage Convention, 10 July 2019, WHC.19/01.

UNESCO World Report: Investing in Cultural Diversity and Intercultural Dialogue, UNESCO, Paris 2009, https://en.unesco.org/interculturaldialogue/resources/130 [accessed: 24.09.2021].

UNESCO, Mexico City Declaration on Cultural Policies, World Conference on Cultural Policies, Mexico City, 26 July - 6 August 1982.

UNESCO, Operational Guidelines on the Implementation of the Convention in the Digital Environment, June 2017, https://en.unesco.org/creativity/node/13628 [accessed: 24.09.2021].

UNESCO, Our Creative Diversity: Report of the World Commission on Culture and Development, UNESCO, Paris 1996, UNESCO Doc. CLT-96/WS-6.

UNESCO, Relshaping Cultural Policies: Advancing Creativity for Development: Monitoring the 2005 UNESCO Convention on the Protection and Promotion of the Diversity of Cultural Expressions, UNESCO, Paris 2018.

Universal Declaration on Cultural Diversity, 2 November 2001, http://www.un-documents. net/udcd.htm [accessed: 24.09.2021].

Voon T., Culture, Human Rights, and the WTO, in: A.F. Vrdoljak (ed.), The Cultural Dimension of Human Rights, Oxford University Press, Oxford 2014.

Voon T., UNESCO and the WTO: A Clash of Cultures?, "International and Comparative Law Quarterly" 2006, Vol. 55(3).

Vrdoljak A.F., Liberty, Equality, Diversity: States, Cultures, and International Law, in: A.F. Vrdoljak (ed.), The Cultural Dimension of Human Rights, Oxford University Press, Oxford 2014.

Wendland W., Intellectual Property and the Protection of Traditional Knowledge and Cultural Expressions, in: B. Hoffman (ed.), Art and Cultural Heritage: Law, Policy and Practice, Cambridge University Press, Cambridge 2006.

Wintemute R., Accommodating Religious Beliefs: Harm, Clothing or Symbols, and Refusals to Serve Others, "Modern Law Review" 2014, Vol. 77.

WIPO, Intergovernmental Committee on Intellectual Property and Genetic Resources, Traditional Knowledge and Folklore, Fifth Session, Geneva, July 7 to 15, 2003, 2 May 2003, WIPO/ GRTKF/IC/5/3.

World Trade Organization, Canada - Certain Measures Concerning Periodicals, 30 June 1997, WT/DS31/AB/R.

World Trends in Freedom of Expression and Media Development: Global Report 2017/2018, UNESCO, Paris 2018.

Xanthaki A., Culture, in: M. Weller, J. Hohmann (eds.), The UN Declaration on the Rights of Indigenous Peoples: A Commentary, Oxford University Press, Oxford 2017.

Xanthaki A., Multiculturalism and International Law: Discussing Universal Standards, "Human Rights Quarterly" 2010, Vol. 32.

Yusuf A., Diversity of Legal Traditions and International Law: Keynote Address, "Cambridge Journal of International and Comparative Law" 2013, Vol. 2(4).

Zampetti A.B., Entrenching Sustainable Human Development in the Design of the Global Agenda after 2015, "Denver Journal of International Law \& Policy" 2020, Vol. 43(3). 